JOURNAL OF MUSICAL ARTS

\title{
The Influence Of Church Music On The Enthusiasm Of The Gereja Beth-E1 Tabernakel Kristus Alfa Omega (GBT KAO) Juwana Congregation In Attending Worship
}

Michael Simanjuntak ${ }^{\bowtie 1}$

Universitas Negeri Semarang, Indonesia

Irfanda Rizki Harmono Sejati

Universitas Negeri Semarang, Indonesia

\begin{tabular}{|c|c|}
\hline Article Info & Abstract \\
\hline $\begin{array}{l}\text { Submitted: September, } \\
2021 \\
\text { Revised: December } 2021 \\
\text { Accepted: December } \\
2021\end{array}$ & $\begin{array}{l}\text { Gereja Beth-El Tabernakel Kristus Alfa Omega (GBT KAO) Juwana is one of the churches in } \\
\text { Juwana with a diverse congregation. With this diversity, GBT KAO Juwana tries to provide worship } \\
\text { that is considered capable of the needs of all congregations through the music presented. The } \\
\text { problem that is often encountered in churches today is the lack of enthusiasm of the congregation } \\
\text { when worship is taking place. Therefore, the formulation that can be studied in this study is how the } \\
\text { influence of church music on the enthusiasm of the GBT KAO Juwana congregation in attending } \\
\text { worship. This study used quantitative research methods. The data collection technique in this study }\end{array}$ \\
\hline $\begin{array}{l}\text { Keywords: } \\
\text { Influence of Music, } \\
\text { Church Music, } \\
\text { Enthusiasm for Worship, } \\
\text { GBT KAO Juwana. }\end{array}$ & $\begin{array}{l}\text { used a questionnaire. The collected questionnaires were processed using a simple linear regression } \\
\text { analysis technique using SPSS. The results show that }(1) \text { the correlations table obtained Pearson } \\
\text { Correlation of } 0,707>0,312 \text { and a significance value of } 0,000<0,05,(2) \text { the coefficients table } \\
\text { obtained } 6,168>1,697 \text { and } 0,000<0,05 \text { significance values, (3) the ANOVA table obtained f count } \\
\text { of } 38,048>4,098 \text { and a significance value of } 0,000<0,05,(4) \text { the model summary table obtained } \mathrm{R} \\
\text { square value of } 0,500=50,0 \% \text {. The conclusions in this study indicate that church music has a } 50 \% \\
\text { effect on the enthusiasm of the GBT KAO Juwana congregation in attending worship. }\end{array}$ \\
\hline
\end{tabular}




\section{INTRODUCTION}

In the Middle Ages, the church played an important role in the life of Western society, including the development of music. At the beginning of this period, Gregorian music (600-1200) has emerged, the first musical art form in the history of European music. According to music experts, the music of the Middle Ages was the artistic perfection peak of Gregorian music. Gregorian music is used in Catholic church religious ceremonies which is monophonic. It means that it only contains one voice without any accompaniment, uses Latin and sometimes Greek, and cannot be sung by anyone so that the participation of ordinary people is very little (Prier, 1991).

In 1517, there was a Protestant Reformation movement by one of the monks of the Catholic church, Martin Luther. This movement began when Martin Luther saw the teaching given at that time was not following what was in the Bible (Wriedt, 2003). Although the reformation is a religious movement, it also has a strong impact on all other aspects of life such as marriage and family, education, humanity and science, political and social order, economy, and arts (Heussi, 1956). Martin Luther was known not only as a monk but a hymn who was productive by writing hymns. His works of hymns influenced the development of singing in Protestant churches (Bainton, 1995). Martin Luther's reformation has a significant impact, one of which is in the field of music. Forms of worship changed, hymnbooks were published, and basic reformation doctrines were taught through the Large and Small Catechism in 1529 (Sunarto, 2021). Martin Luther linked the high arts, folk music, the whole class, clergy and laity, men, women, and children (Brown, 2005). The dispute between Catholics and Protestants that occurred in Europe affected the existence of religion in Indonesia. The spread of Catholic teachings previously carried out by Portuguese missionaries was monopolized by Vereenigde Oostindische Compagnie (VOC) to spread the teachings of Protestant (Cipta, 2020).
After going through the war of independence, Indonesia finally got its full sovereignty. This situation affected the development of the church in Indonesia. The church began to grow and create various denominations. A denomination is a religious group that can be identified under one name, structure, and doctrine (Ukur \& Cooley, 1978). The church denominations in Indonesia nowadays are the Reformed Church (Calvinist), Lutheran Church (Evangelical Lutheran), Evangelical Church, Methodist Church, Mennonite Church, Baptist Church, Pentecostal Church (Charismatic). In this research, the researchers focused on the Pentecostal Church denomination (Charismatic). There are quite a few churches in this denomination, such as Gereja Mawar Sharon (GMS), Gereja Bethany Indonesia (Bethany), Gereja Bethel Indonesia (GBI) termasuk Gereja Beth-El Tabernakel (GBT), etc.

Gereja Beth-El Tabernakel (GBT) is one of the fastest-growing churches in Indonesia. Gereja Beth-El Tabernakel (GBT) can be found in various regions of Indonesia with varied names such as Gereja Beth-El Tabernakel Kristus Alfa Omega (GBT KAO), Gereja Beth-El Tabernakel (GBT) Maranatha and others. Usually, the last name is followed by the name of the area where the church is located, such as Gereja Beth-El Tabernakel Kristus Alfa Omega (GBT KAO) Juwana.

Gereja Beth-El Tabernakel Kristus Alfa Omega (GBT KAO) Juwana is one of the churches in Juwana with a diverse congregation. With this diversity, GBT KAO Juwana tries to present worship that is considered capable of the needs of all congregations without leaving the Christian values or the main essence contained in the Bible. GBT KAO Juwana tries to constantly renew the liturgy in worship to meet the physical and spiritual needs of its congregation in response to its duties and vocations. The fulfillment of this need can be provided through the selection of themes that are directly related to the daily realities of the congregation, the presentation of sermons that are not 
boring, the variations of worship, and the presentation of church music that can express the congregations.

Problems encountered by the churches nowadays are lacking the enthusiasm of the congregation when worship is taking place, including the worship at GBT KAO Juwana. One of the reasons for the lack of enthusiasm of the congregation at GBT KAO Juwana is the music presented. By directly observing the attitude of the GBT KAO Juwana congregation during worship and conducting random interviews with active church members, servants of God, musicians, worshipers, and lay congregations, the author is interested in researching specifically how the influence of church music on the enthusiasm of the GBT KAO Juwana congregation in attending worship.

\section{METHOD}

This research is quantitative. Quantitative research is research where the data is in the form of numbers and can be analyzed or processed with statistics. This quantitative research uses the type of correlation research. Correlation research aims to find the relationship between one or more variables. The results of correlation research can determine whether a variable is positively correlated, negatively correlated, or even uncorrelated to other variables. Correlation research allows researchers to collect more data to examine the relationship (Sugiyono, 2010).

This thesis research was carried out at GBT KAO Juwana. The research time and the data collection were carried out in July 2021. This research was conducted at GBT KAO Juwana because it has a diverse congregation and has a population supporting the quantitative research methods.

There are two variables in this study, namely the independent variable and the dependent variable. The independent variable is a variable affecting or becoming the change causes or the emergence of the dependent variable (Sugiyono, 2010).The independent variable $(\mathrm{X})$ in this study is church music. The dependent variable (Y) is the variable influenced or becoming the consequence because of the independent variable (Sugiyono, 2010). The dependent variable (Y) in this study is the enthusiasm for worship.

The population in this study was taken from the entire congregation of GBT KAO Juwana, totaling 40 congregations. The sample in this study was the entire congregation of GBT KAO Juwana, totaling 40 congregations.

The data collection technique in this study used a questionnaire. The questionnaire is a list of statements sent to respondents, either directly or indirectly (by post or intermediary). The use of this questionnaire has the aim of making it easier for the subject to answer according to the actual conditions and circumstances (Husaini, 2003). Seeing the conditions when this research took place, there was the COVID-19 outbreak. Therefore, the researchers researched with a system door to door because all church activities were still done online. Questionnaires were distributed to all congregations with health protocols such as wearing masks, using hand sanitizer, and applying social distancing. In this study, two instruments were used for data collection, namely to collect data on the church music variable (X) and the enthusiasm of worship variable (Y). The instrument in question is in the form of a questionnaire that provides a statement to the respondent, where the respondent answers it by giving a checklist sign in the column provided

The instrument used in this study is a Likert scale with 5 scales. The lowest score is assigned a number 1 and the highest score is assigned a score of 5. This scale serves as a guide for measuring incoming data from the population.

The data analysis technique used in this research is simple linear regression analysis. The simple linear regression analysis is used to measure the influence of the independent variable on the dependent variable (Sugiyono, 2010). Data analysis was carried out with the help of SPSS to simplify calculations. 


\section{RESULTS AND DISCUSSION}

Based on the results obtained using simple regression linear analysis, it shows that church music influences the enthusiasm of the GBT KAO Juwana congregation in attending worship which can be seen from the following table:

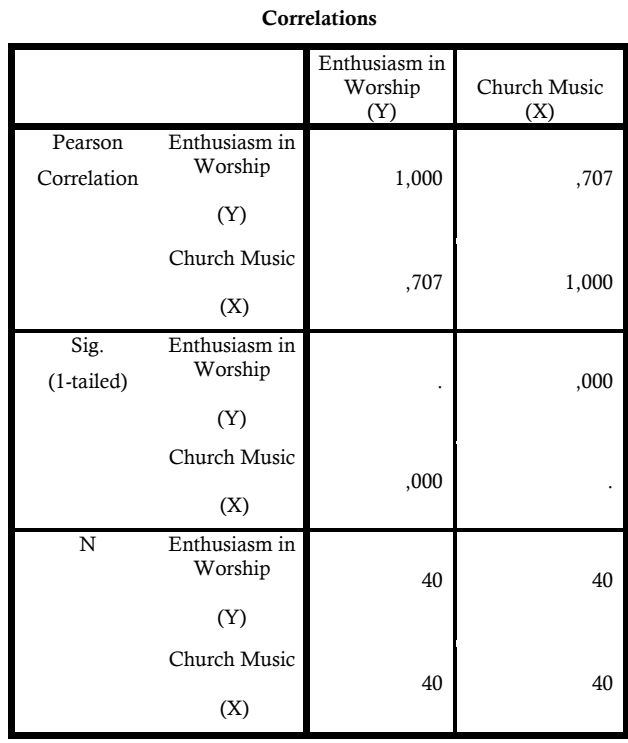

Table 1. Correlations

Based on the correlations table above, it is obtained $r$ count (Pearson Correlation) of $0,707>0,312$ and $a$ significant value of $0,000<0,05$. These results indicate that there is an influence of church music on enthusiasm in worship.

\begin{tabular}{|c|c|c|c|c|c|}
\hline \multicolumn{6}{|c|}{ Coefficients $^{a}$} \\
\hline \multirow[b]{2}{*}{ Model } & \multicolumn{2}{|c|}{$\begin{array}{l}\text { Unstandardized } \\
\text { Coefficients }\end{array}$} & \multirow{2}{*}{\begin{tabular}{|c|}
$\begin{array}{c}\text { Standardized } \\
\text { Coefficients }\end{array}$ \\
Beta \\
\end{tabular}} & \multirow[b]{2}{*}{$\mathrm{t}$} & \multirow[b]{2}{*}{ Sig. } \\
\hline & B & $\begin{array}{l}\text { Std. } \\
\text { Error }\end{array}$ & & & \\
\hline 1 (Constant) & 16,126 & 5,200 & & 3,101 & ,004 \\
\hline $\begin{array}{l}\text { Church } \\
\text { Music } \\
\text { (X) }\end{array}$ & 645 & ,105 & ,707 & 6,168 & ,000 \\
\hline
\end{tabular}

Table 2. Coefficients ${ }^{\mathrm{a}}$

Based on the coefficients table above, it is obtained t count of $6,168>$ 1,697 and a significant value of $0,000<$ 0,05 . These results indicate that there is an influence of church music on enthusiasm in worship.

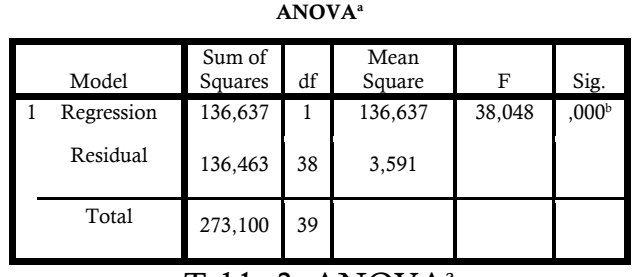

Table 3. ANOVA ${ }^{\mathrm{a}}$

Based on the ANOVA $^{\mathrm{a}}$ table above, it is obtained f count of $38,048>$ 4,098 and a significant value of $0,000<$ 0,05 . These results indicate that there is an influence of church music on enthusiasm in worship

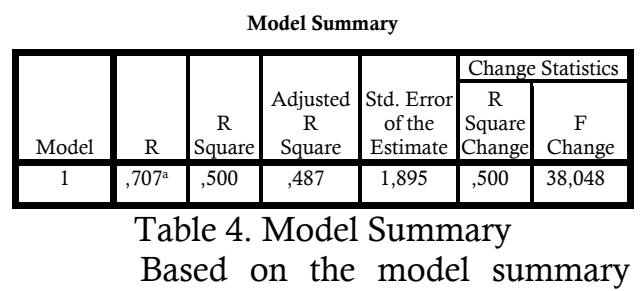
table above, the $\mathrm{R}$ square value is $0,500=$ $50 \%$. The value indicates that church music affects the worship enthusiasm representing $50 \%$ and the residual is influenced by other variables that are not included in this study.

Church music is a very important element because most portions of church worship have musical elements (BPMS GKI, 2012). Worship at GBT KAO Juwana is modern contemporary worship where church music has a very important role. Church music and worship cannot be separated to achieve maximum results. Church music can be a medium to deliver people in praising God because it can affect a person's emotions (Mawene, 2004). Church music can create congregation awareness of God's presence and can create a more expressive worship atmosphere.

In worship in the church, music has a role in conveying the message contained in the song sung. When church music can convey the message contained in a song, the church congregation will more easily understand the meaning and purpose of the song. It will affect the enthusiasm of the congregation to come to worship and increase their faith in God. In 
conveying the message of a song sung during worship, it can be done in many ways, not only through verbal language (lyrics/poems), but also through nonverbal language (dynamics, tempos, and rhythm). This non-verbal language can affect a person's emotions. Church music can bring the congregation more wisdom in carrying out worship, not only because of the lyrics or songs of praise, worship, and offerings but because of the musical elements contained in church music. The elements in church music like the use of good dynamics can touch the hearts of the congregation to better appreciate the songs sung.

The power of church music is not limited by language and one's perception of an object but it can be influenced by the interpersonal interactions of the congregation (Suryanto, 2014). The mood can certainly be influenced by church music and can increase concentration so that the congregation can notice fully the words that match the mood (Djohan, 2005). The connection with the research on the influence of church music on the enthusiasm of the GBT KAO Juwana congregation in attending worship is that church music can make the congregation feel, understand, and interpret songs sung so that the congregation can be more enthusiastic in participating in worship.

\section{CONCLUSION}

From the research results on the influence of church music on the enthusiasm of the GBT KAO Juwana congregation in attending worship, it can be concluded that church music has a $50 \%$ effect on the enthusiasm of the GBT KAO Juwana congregation in attending worship and the others are influenced by other variables that are not included in this study such as sermons, offerings, church environment, and others.

\section{REFERENCES}

Bainton, R. (1995). Here I Stand: a Life of Martin Luther. Penguin.

BPMS GKI. (2012). Musik dalam Ibadah. Grafika Kreasindo.

Brown, C. B. (2005). Singing the Gospel:
Lutheran Hymns and the Success of the Reformation.

Cipta, S. E. (2020). 100\% Katolik 100\% Iindonesia. Jurnal Sosiologi Agama, 14(1), 35-50.

Djohan. (2005). Psikologi Musik. Buku Baik.

Heussi, K. (1956). Karl Heussi.

Husaini, U. (2003). Metodologi Penelitian Sosial. Bumi Aksara.

Mawene. (2004). Gereje yang Bernyanyi. Andi.

Prier, K. E. (1991). Sejarah Musik. Pusat Musik Liturgi.

Sugiyono. (2010). Metodologi Penelitian Kuantitatif, Kualitatif dan $R \& D$. Alfabeta.

Sunarto, I. R. H. (2021). Martin Luther dan Reformasi Musik Gereja. Tonika: Jurnal Penelitian Dan Pengkajian Seni, 4(1).

Suryanto, L. K. D. (2014). Pengaruh Musik Iringan Ibadah Impresif Terhadap Jumlah Jemaat Gki Gejayan Yogyakarta.

Ukur, F., \& Cooley, F. L. (1978). Jerih dan Juang. LPS-DGI.

Wriedt, M. (2003). "Luther's Theology," in The Cambridge Companion to Luther. Cambridge University Press. 